\title{
Changes in the Antioxidant System in Soybean Leaves Infected by Corynespora cassiicola
}

\author{
Alessandro Antônio Fortunato, Daniel Debona, Arthur Martins Almeida Bernardeli, and Fabrício Ávila Rodrigues
}

Universidade Federal de Viçosa, Departamento de Fitopatologia, Laboratório da Interação Planta-Patógeno, Viçosa, Minas Gerais State 36570900, Brazil.

Accepted for publication 26 February 2015.

\begin{abstract}
Fortunato, A. A., Debona, D., Bernardeli, A. M. A., and Rodrigues, F. A. 2015. Changes in the antioxidant system in soybean leaves infected by Corynespora cassiicola. Phytopathology 105:1050-1058.

Considering the importance of target spot, caused by the fungus Corynespora cassiicola, to reduce soybean yield in Brazil and that more basic information regarding the soybean- $C$. cassiicola interaction is needed, the present study aimed to investigate whether the cellular damage caused by $C$. cassiicola infection could activate the antioxidant system and whether a more efficient antioxidant system could be associated with an increase in soybean resistance to target spot. The activities of the antioxidant enzymes superoxide dismutase, catalase, peroxidase, ascorbate peroxidase, glutathione peroxidase, glutathione reductase, glutathione S-transferase as well as the concentrations of ascorbate (AsA), hydrogen

peroxide $\left(\mathrm{H}_{2} \mathrm{O}_{2}\right)$, superoxide $\left(\mathrm{O}_{2}{ }^{--}\right)$, and malondialdehyde (MDA) were measured in soybean plants from two cultivars differing in resistance to the pathogen. The number of lesions per square centimeter was significantly reduced by $14 \%$ in plants from cultivar Fundacep 59 compared with plants from cultivar TMG 132. The area under the disease progress curve was significantly lower, by $15 \%$, in plants from Fundacep 59 than in plants from TMG 132. Generally, antioxidant enzyme activities and AsA concentration significantly increased in response to $C$. cassiicola infection in plants from both cultivars, however more prominent increases were recorded for plants from Fundacep 59. The concentrations of MDA, $\mathrm{H}_{2} \mathrm{O}_{2}$, and $\mathrm{O}_{2}{ }^{--}$also increased, particularly for plants from TMG 132. The results from this study highlight the importance of a more efficient antioxidative system in the removal of reactive oxygen species generated in soybean plants during C. cassiicola infection, contributing to the resistance to target spot.
\end{abstract}

Soybean (Glycine max (L.) Merrill) is one of the most profitable crops grown worldwide, but many fungal diseases greatly contribute to reduced grain quality and yield (Sinclair 1999). In Brazil, target spot, which is caused by the necrotrophic fungus Corynespora cassiicola (Berk and MA Curtis) CT Wei., has become increasingly important (Godoy et al. 2012; Teramoto et al. 2013). Symptoms consisted of roughly circular, necrotic leaf lesions from minute to $11 \mathrm{~mm}$ in diameter, though typically approximately 4 to $5 \mathrm{~mm}$ in diameter, and with a yellow margin (Sinclair 1999). The necrotic lesions occasionally are large and are of roughly circular to irregular form, which have alternating light and dark rings surrounded by a dull green or yellowish green halo (Almeida et al. 2005; Sinclair 1999). As the lesions expand, they can exhibit a zonate pattern that significantly decreases the photosynthetically active leaf area (Sinclair 1999), and premature defoliation may occur in susceptible cultivars (Almeida et al. 2005; Sinclair 1999). The fungus survives between seasons on soybean debris and seed (Almeida et al. 2005; Sinclair 1999). Elevated temperatures (28 \pm $2{ }^{\circ} \mathrm{C}$ ) associated with high relative humidity in the mid-to-late soybean growing season, especially when the plant canopy has closed, favor the occurrence of severe target spot epidemics (Godoy et al. 2012). Target spot management has been difficult to achieve because few cultivars have a desirable level of resistance and isolates of $C$. cassiicola resistant to the benzimidazole fungicides have recently been detected in Brazil (Teramoto et al. 2013; Xavier et al. 2013).

Because $C$. cassiicola is able to secrete many lytic enzymes and non-host-selective toxins, such as cassiicolin, the fungus can use these macromolecules during its process of pathogenesis for

Corresponding author: F. A. Rodrigues; E-mail address: fabricio@ufv.br a massive colonization of host's tissue (Barthe et al. 2007; Onesirosan et al. 1975b). The reactive oxygen species (ROS) have been associated with plant defense due to their antimicrobial activity or their contribution to the lignification of host cell walls that constrains pathogen colonization of the host tissue (Daub et al. 2013; Grant and Loake 2000). However, ROS are strong oxidizing agents that can damage essential macromolecules, such as membrane lipids, pigments, nucleic acids, carbohydrates, and proteins, and therefore contribute to premature leaf senescence (Gill and Tuteja 2010). To maintain an adequate balance between the production and removal of ROS, plants have evolved an antioxidant system (Mittler 2002). This system involves a wide range of compounds, including reduced ascorbate (AsA) and glutathione (GSH), carotenoids, fiavonoids, and other phenolics in addition to miscellaneous antioxidant enzymes, which include superoxide dismutase (SOD), catalase (CAT), peroxidase (POX), ascorbate peroxidase (APX), glutathione peroxidase (GPX), glutathione$S$-transferase (GST), and glutathione reductase (GR) (Asada 1999; Malenčić et al. 2010; Mittler et al. 2004; Mittler 2002; Noctor and Foyer 1998). During the pathogenesis of the necrotrophic fungus Botrytis cinerea in tomato plants, peroxisomal CAT activity increased in the infected plants during the first stages of fungal infection, but it strongly declined during the advanced stages compared with healthy plants (Kużniak and Skłodowska 2005). Increases in the activities of antioxidant SOD, POX, and reduced glutathione during fungal infection were associated with the removal of ROS in the soybean-Sclerotinia sclerotiorum interaction (Malenčić et al. 2010). Soybean seedlings infected by Rhizoctonia solani also exhibited a significant increase in SOD activity compared with noninfected seedlings (Kiprovski et al. 2012). During Pyricularia oryzae infection in wheat plants, Debona et al. (2012) showed significant increases in SOD, CAT, POX, APX, GST, and GR activities in plants from a resistant cultivar in comparison with plants from a susceptible one. In agreement with 
previous information of the efficiency of the removal of ROS during pathogenesis on resistant plants, Lanubile et al. 2012 observed increases in SOD activity in maize ears from resistant cultivar infected by Fusarium verticillioides compared with the susceptible one.

Considering the importance of target spot to soybean production and that more basic information regarding the soybean-C. cassiicola interaction is needed, the present study tested the following hypotheses: (i) C. cassiicola infection of soybean plants increases ROS production and cellular damage, activating the antioxidant system, and (ii) a more efficient antioxidant system is associated with an increase in soybean resistance to target spot.

\section{MATERIALS AND METHODS}

Soybean growth. A total of 10 soybean seed from TMG 132 and Fundacep 59, susceptible and moderately resistant to target spot, respectively (Godoy et al. 2012; Pitol et al. 2011), were sown into 2 liter plastic pots (Ecovaso, Jaguariúna, SP, Brazil) containing $2 \mathrm{~kg}$ of Tropstrato (Vida Verde, Mogi Mirim, SP, Brazil) substrate composed of a 1:1:1 mixture of pine bark, peat, and expanded vermiculite. Five days after seedling emergence, each pot was thinned to two seedlings, which were fertilized weekly with $50 \mathrm{ml}$ of a nutrient solution prepared using deionized water that contained $40 \mathrm{mM} \mathrm{KNO}_{3}, 10 \mathrm{mM} \mathrm{NH}_{4} \mathrm{H}_{2} \mathrm{PO}_{4}, 10 \mathrm{mM} \mathrm{MgSO} \mathrm{M}_{4} \cdot 7 \mathrm{H}_{2} \mathrm{O}, 15 \mathrm{mM}$ $\mathrm{Ca}\left(\mathrm{NO}_{3}\right)_{2} \cdot 4 \mathrm{H}_{2} \mathrm{O}, 2.4 \mathrm{mM} \mathrm{ZnSO} 4 \cdot 7 \mathrm{H}_{2} \mathrm{O}, 3 \mathrm{mM} \mathrm{H} \mathrm{BO}_{3}, 10 \mathrm{mM}$ $\mathrm{K}_{2} \mathrm{SO}_{4}, 3.3 \mathrm{mM} \mathrm{CH}_{4} \mathrm{~N}_{2} \mathrm{O}$, and $7.5 \mathrm{mM} \mathrm{NH}_{4} \mathrm{H}_{2} \mathrm{SO}_{4}$ (Dallagnol et al. 2012). Plants were watered with deionized water as needed. The plants were kept in a greenhouse (relative humidity of $65 \pm 5 \%$ and temperature of $30 \pm 5^{\circ} \mathrm{C}$ ) and were grown for 45 days (approximately V9 growth stage) (Fehr et al. 1971).

Inoculation procedure. A pathogenic isolate of $C$. cassiicola, obtained from symptomatic leaves of soybean plants collected in the municipality of Rio Verde, Goiás State, Brazil, was used to inoculate the plants. The obtained $C$. cassiicola isolate was preserved using Castellani's method, which consisted of five plugs containing the PDA media and mycelium ( $5 \mathrm{~mm}$ diameter) being placed in a flask containing $5 \mathrm{ml}$ of distilled sterilized water (Dhingra and Sinclair 1995). At 14 days before inoculation, plugs of mycelium from cultures grown on potato dextrose agar were placed in Petri dishes containing carrot leaf-pea dextrose agar (CL-PeDA) media. The CL-PeDA media was prepared using $200 \mathrm{mg}$ of carrot leaves, $100 \mathrm{~g}$ of fresh peas, $20 \mathrm{~g}$ dextrose, and $20 \mathrm{~g}$ of agar. Carrot leaves and peas were mixed in a blender to obtain a homogenous mixture, which was then sieved to remove the excess solids. Fragments of 3-day-old fungal mycelia were transferred and homogenously spread onto a fresh plate of CL-PeDA and placed in a growth chamber with a 12 -h photoperiod at $25^{\circ} \mathrm{C}$ for 4 days. After this period, the fungal mycelia were stressed using a Drigalski spatula in a laminar flow chamber to avoid contamination (Onesirosan et al. 1975a). The plates were subsequently maintained in a growth chamber under continuous white light (40 W lamps alternately distributed to provide a light intensity of $165.3 \mu \mathrm{mol} \mathrm{s}{ }^{-1} \mathrm{~m}^{-2}$ ) for 6 days until the production of conidia. Conidia were carefully removed from Petri dishes with a soft-bristle brush using water containing gelatin $(1 \% \mathrm{wt} / \mathrm{vol})$. The plants were grown at greenhouse conditions $\left(25 \pm 2{ }^{\circ} \mathrm{C}\right.$ during the day and $20 \pm 2^{\circ} \mathrm{C}$ at night) prior to inoculation. The conidial suspension of $C$. cassiicola was prepared by adding approximately $30 \mathrm{ml}$ of water in each plate $(10 \mathrm{~cm}$ diameter) with abundant sporulation, and then brushing to remove the conidia from the mycelium resulting in a concentrated suspension that was calibrated to a final concentration of $5 \times 10^{4}$ conidia ml-1 . A total of $20 \mathrm{ml}$ of conidial suspension was applied as a fine mist using a VL airbrush atomizer (Paache Airbrush Co., Chicago, IL) to both the adaxial and abaxial leaf surfaces of each plant. After inoculation, plants were maintained in a plastic mist growth chamber (MGC) inside a greenhouse for the duration of the experiments. The MGC was constructed of wood ( $2 \mathrm{~m}$ wide, $1.5 \mathrm{~m}$ high, and $5 \mathrm{~m}$ long) and covered with transparent plastic $(100 \mu \mathrm{m}$ thick). The maximum natural photon flux density at plant canopy height was $\approx 700 \mu \mathrm{mol} \mathrm{m} \mathrm{m}^{-2} \mathrm{~s}^{-1}$ and the temperature was $25 \pm 2{ }^{\circ} \mathrm{C}$ during the day and $20 \pm 2{ }^{\circ} \mathrm{C}$ at night. The relative humidity was maintained at $90 \pm 5 \%$ using a misting system that sprayed mist from nozzles (model NEB-100, KGF Co., São Paulo, Brazil) above the plant canopy for $15 \mathrm{~s}$ every $30 \mathrm{~min}$. The temperature and relative humidity were measured with a thermohygrograph (TH-508, Impac, Brazil).

Disease assessment. Target spot severity (TSS) on the eighth trifoliate leaf was evaluated for plants from each replication and treatment at 4, 6, 8, and 10 days after inoculation (dai) using a standard area diagram set (Soares et al. 2009). The TSS data were used to calculate the area under the disease progress curve (AUDPC) according to Shaner and Finney (1977). At 10 dai, the number of lesions (NL) per square centimeter of leaflet area was counted at five random places on the eighth trifoliate leaves with the aid of a hand-held microscope $(\times 15)$.

Biochemical analysis. For all biochemical assays, the sixth, seventh, eighth, and ninth trifoliate leaves, counted from the base to the top, of plants from each treatment and replication were collected at 4, 6, 8, and 10 dai. Leaf samples were kept in liquid nitrogen during sampling and subsequently stored at $-80^{\circ} \mathrm{C}$ until further analysis.

Determination of enzyme activities. To determine the activities of SOD, CAT, POX, APX, GPX, and GST, a total of $200 \mathrm{mg}$ of homogenized leaf tissue was ground into a fine powder using a mortar and pestle while adding liquid nitrogen. The fine powder was immediately homogenized in $2 \mathrm{ml}$ of a solution containing $50 \mathrm{mM}$ of a potassium phosphate buffer $(\mathrm{pH} \mathrm{6.8)}$, $0.1 \mathrm{mM}$ ethylenediaminetetraacetic (EDTA), $1 \mathrm{mM}$ phenylmethylsulfonyl fluoride (PMSF), and 2\% (wt/vol) polyvinylpolypyrrolidone (PVPP). The homogenate was then centrifuged at $12,000 \times g$ for $15 \mathrm{~min}$ at $4^{\circ} \mathrm{C}$, and the supernatant was used as a crude enzyme extract. To determine the activity of glutathione reductase (GR), a total of $200 \mathrm{mg}$ of homogenized leaf tissue was ground as described above, and the extraction solution used to homogenize the fine powder contained $100 \mathrm{mM}$ potassium phosphate buffer (pH 7.5), $0.1 \mathrm{mM}$ EDTA, $1 \mathrm{mM}$ DL-dithiothreitol, $1 \mathrm{mM}$ PMSF, and $2 \%(\mathrm{wt} / \mathrm{vol})$ PVPP in a final volume of $2 \mathrm{ml}$. The homogenate was centrifuged as previously described.

The SOD activity was determined using the method described by Del Longo et al. (1993), which measures the capacity of SOD to photochemically reduce the $p$-nitrotetrazolium blue (NTB) in the reaction solution. The reaction was initiated following the addition of $40 \mu \mathrm{l}$ of the crude enzyme extract to $960 \mu \mathrm{l}$ of a mixture containing $50 \mathrm{mM}$ potassium phosphate buffer ( $\mathrm{pH} 7.8), 13 \mathrm{mM}$ methionine, $75 \mu \mathrm{M}$ NTB, $0.1 \mathrm{mM}$ EDTA, and $2 \mu \mathrm{M}$ riboflavin. The reaction was carried out at $25^{\circ} \mathrm{C}$ under $15 \mathrm{~W}$ lamp light per $10 \mathrm{~min}$. Following light exposure, the light was turned off, and the production of formazan blue, which resulted from the photoreduction of NTB, was measured at $560 \mathrm{~nm}$ with a spectrophotometer (Evolution 60, Thermo Fisher Scientific Inc., MA) (Giannopolitis and Ries 1977). For the control samples, the reaction mixture was maintained in darkness for $10 \mathrm{~min}$, and the absorbance was measured at $560 \mathrm{~nm}$. The values obtained from the experimental samples (light) were subtracted from the values obtained from the control samples to determine the SOD activity. The amount of enzyme necessary to inhibit NBT photoreduction by $50 \%$ was defined as one unit of SOD (Beauchamp and Fridovich 1971).

The CAT activity was determined following the method proposed by Cakmak and Marschner (1992). Briefly, the reaction was initiated following the addition of $25 \mu \mathrm{l}$ of the crude enzyme extract to $975 \mu \mathrm{l}$ of a reaction mixture consisting of $50 \mathrm{mM}$ potassium phosphate buffer ( $\mathrm{pH} \mathrm{6.8)}$ ) and $20 \mathrm{mM} \mathrm{H}_{2} \mathrm{O}_{2}$. The determination of CAT activity was based on the rate of $\mathrm{H}_{2} \mathrm{O}_{2}$ decomposition measured in the spectrophotometer at $240 \mathrm{~nm}$ for $1 \mathrm{~min}$ at $25^{\circ} \mathrm{C}$. An extinction coefficient of $36 \mathrm{M}^{-1} \mathrm{~cm}^{-1}$ was used to calculate CAT activity (Anderson et al. 1995).

The POX activity was assayed following the colorimetric determination of pyrogallol oxidation according to Kar and Mishra (1976). 
The reaction was started after the addition of $15 \mu \mathrm{l}$ of the crude enzyme extract to $985 \mu \mathrm{l}$ of a reaction mixture containing $25 \mathrm{mM}$ potassium phosphate $(\mathrm{pH} 6.8), 20 \mathrm{mM}$ pyrogallol, and $20 \mathrm{mM}$ $\mathrm{H}_{2} \mathrm{O}_{2}$. The POX activity was measured by the absorbance of colored purpurogallin at $420 \mathrm{~nm}$ for $1 \mathrm{~min}$ at $25^{\circ} \mathrm{C}$. An extinction coefficient of $2.47 \mathrm{mM}^{-1} \mathrm{~cm}^{-1}$ was used to calculate POX activity (Chance and Maehley 1955).

The APX activity was assayed using the method proposed by Nakano and Asada (1981). The reaction was started following the addition of $25 \mu \mathrm{l}$ of the crude enzyme extract to $975 \mu \mathrm{l}$ of a reaction mixture containing $50 \mathrm{mM}$ potassium phosphate buffer ( $\mathrm{pH} 6.8$ ), $1 \mathrm{mM} \mathrm{H} \mathrm{H}_{2}$, and $0.8 \mathrm{mM}$ ascorbate. The APX activity was measured via the rate of ascorbate oxidation at $290 \mathrm{~nm}$ for $1 \mathrm{~min}$ at $25^{\circ} \mathrm{C}$. An extinction coefficient of $2.8 \mathrm{mM}^{-1} \mathrm{~cm}^{-1}$ was used to calculate APX activity.

The GPX activity was determined following the addition of $50 \mu \mathrm{l}$ of the crude enzyme extract to $950 \mu$ of a mixture containing $50 \mathrm{mM}$ potassium phosphate buffer ( $\mathrm{pH}$ 7.0), $1 \mathrm{mM}$ EDTA, $0.114 \mathrm{M} \mathrm{NaCl}$, $1 \mathrm{mM}$ reduced glutathione (GSH), $0.2 \mathrm{mM}$ NADPH, $0.25 \mathrm{mM}$ $\mathrm{H}_{2} \mathrm{O}_{2}$, and $1 \mathrm{U}$ of GR (Nagalakshmi and Prasad 2001). The enzyme activity was measured as a decrease in absorbance at $340 \mathrm{~nm}$ for $1 \mathrm{~min}$ at $30^{\circ} \mathrm{C}$. An extinction coefficient of $6.22 \mathrm{mM}^{-1} \mathrm{~cm}^{-1}$ was used to calculate GPX activity (Anderson and Davis 2004).

The GR activity was assayed following the method described by Carlberg and Mannervik (1985). Briefly, the reaction was initiated after the addition of $50 \mu \mathrm{l}$ of the crude enzyme extract to $950 \mu \mathrm{l}$ of a mixture containing $100 \mathrm{mM}$ potassium phosphate ( $\mathrm{pH} 7.5), 1 \mathrm{mM}$ EDTA, $1 \mathrm{mM}$ oxidized glutathione (GSSG), and $0.1 \mathrm{mM}$ NADPH that was prepared in $0.5 \mathrm{mM}$ of Tris- $\mathrm{HCl}$ buffer $(\mathrm{pH} 7.5)$. The decrease in absorbance was determined at $340 \mathrm{~nm}$ for $1 \mathrm{~min}$ at $30^{\circ} \mathrm{C}$. An extinction coefficient of $6.22 \mathrm{mM}^{-1} \mathrm{~cm}^{-1}$ was used to calculate GR activity (Foyer and Halliwell 1976).

The methodology proposed by Habig et al. (1974) was used to determine GST activity. First, $75 \mu \mathrm{l}$ of the crude enzyme extract was added to $925 \mu \mathrm{l}$ of a reaction mixture containing $50 \mathrm{mM}$ potassium phosphate buffer ( $\mathrm{pH} 6.5$ ) and $50 \mathrm{mM}$ reduced GSH. Next, the reaction was initiated by the addition of $500 \mu \mathrm{l}$ of $30 \mathrm{mM}$ 1-chloro2,4-dinitrobenzene and the absorbance was measured at $340 \mathrm{~nm}$ over $3 \mathrm{~min}$ at $25^{\circ} \mathrm{C}$. The GST activity was determined using an extinction coefficient of $9.6 \mathrm{mM}^{-1} \mathrm{~cm}^{-1}$ (Habig et al. 1974).

The enzyme activity was expressed on a protein basis and its concentration was determined according to the method of Bradford (1976).

Determination of AsA concentration. The AsA concentration was determined following the method described by Kampfenkel et al. (1995). A total of $300 \mathrm{mg}$ of leaf tissue was homogenized in $2 \mathrm{ml}$ of $6 \%(\mathrm{wt} / \mathrm{vol}$ ) acid trichloroacetic (TCA) and centrifuged at $15,000 \times \mathrm{g}$ for $5 \mathrm{~min}$ at $4{ }^{\circ} \mathrm{C}$. Aliquots of $200 \mu \mathrm{l}$ of the crude extract were added to $800 \mu$ of $0.2 \mathrm{M}$ sodium phosphate buffer (pH 7.4). The mixture was incubated at $42^{\circ} \mathrm{C}$ for $15 \mathrm{~min}$. Subsequently, $1.0 \mathrm{ml}$ of $10 \%$ (wt/vol) TCA, $800 \mu \mathrm{l}$ of $42 \%$ (vol $/ \mathrm{vol}$ ) $\mathrm{H}_{3} \mathrm{PO}_{4}, 800 \mu \mathrm{l}$ of $4 \%$ (wt/vol) $2,2^{\prime}-$ dipyridyl (dissolved in $70 \%$ ethanol), and $400 \mu \mathrm{l}$ of $3 \%$ (wt/vol) $\mathrm{FeCl}_{3}$ were added to the mixture. After vigorous stirring, the mixture was incubated at $42^{\circ} \mathrm{C}$ for $40 \mathrm{~min}$. The reaction was then stopped in an ice bath, and the absorbance was measured at $525 \mathrm{~nm}$. The AsA concentration was determined according to an AsA calibration curve (Sigma-Aldrich, São Paulo, Brazil).

Determination of malondialdehyde (MDA) concentration. The oxidative damage in the leaf cells was determined as the concentration of the total 2-thiobarbituric acid (TBA) reactive substances and expressed as MDA equivalents according to Cakmak and Horst (1991). First, $100 \mathrm{mg}$ of leaf tissue was ground into a fine powder using a mortar and pestle while adding liquid nitrogen. Then, the fine powder was homogenized in $2 \mathrm{ml}$ of $0.1 \%$ (wt/vol) trichloracetic acid (TCA) solution. The homogenate was centrifuged at $12,000 \times g$ for $15 \mathrm{~min}$ at $4^{\circ} \mathrm{C}$. After centrifugation, $500 \mu \mathrm{l}$ of the supernatant was reacted with $1.5 \mathrm{ml}$ of TBA solution ( $0.5 \%$ in $20 \%$ TCA) in a ThermoMixer (Eppendorf, Hamburg,
Germany) at $95^{\circ} \mathrm{C}$ for $30 \mathrm{~min}$. After this period, the reaction was stopped in an ice bath. The samples were centrifuged at $9,000 \times g$ for $10 \mathrm{~min}$, and the specific absorbance was determined at $532 \mathrm{~nm}$. The nonspecific absorbance was estimated at $600 \mathrm{~nm}$ and subtracted from the specific absorbance value. An extinction coefficient of $155 \mathrm{mM}^{-1} \mathrm{~cm}^{-1}$ was used to calculate the MDA concentration (Heath and Packer 1968).

Determination of hydrogen peroxide $\left(\mathrm{H}_{2} \mathrm{O}_{2}\right)$ concentration. The method described by Kuo and Kao (2003) was used to assay the concentration of $\mathrm{H}_{2} \mathrm{O}_{2}$. Initially, a total of $100 \mathrm{mg}$ of homogenized leaf tissue was ground into a fine powder using a mortar and pestle while adding liquid nitrogen. The fine powder was homogenized with an extraction mixture containing $50 \mathrm{mM}$ potassium phosphate buffer ( $\mathrm{pH} \mathrm{6.5)}$ and $1 \mathrm{mM}$ hydroxylamine in a volume of $2 \mathrm{ml}$. The homogenate was centrifuged at $10,000 \times g$ for $15 \mathrm{~min}$ at $4^{\circ} \mathrm{C}$ and the supernatant was collected. The reaction was initiated with the addition of $100 \mu \mathrm{l}$ of the supernatant to a reaction mixture containing $100 \mu \mathrm{M}$ ferric ammonium sulfate $\left(\mathrm{FeNH}_{4}\left[\mathrm{SO}_{4}\right]\right), 25 \mathrm{mM}$ sulfuric acid, $250 \mu \mathrm{M}$ xylenol orange and $100 \mathrm{mM}$ sorbitol in a volume of $2 \mathrm{ml}$ (Gay and Gerbicki 2000). The samples were kept in darkness for $30 \mathrm{~min}$, and the absorbance was determined at $560 \mathrm{~nm}$. The controls for the reagents and crude extracts were prepared under the same conditions and subtracted from the sample. The $\mathrm{H}_{2} \mathrm{O}_{2}$ concentration was estimated based on a standard curve for $\mathrm{H}_{2} \mathrm{O}_{2}$ (Sigma-Aldrich, São Paulo, Brazil).

Determination of superoxide $\left(\mathrm{O}_{2}{ }^{-}\right)$concentration. A total of $200 \mathrm{mg}$ of leaf tissue was ground into a fine powder with a mortar and pestle with added liquid nitrogen to determine the concentration of $\mathrm{O}_{2}{ }^{--}$. The fine powder was homogenized in an ice bath in $2 \mathrm{ml}$ of a solution containing $100 \mathrm{mM}$ sodium phosphate buffer ( $\mathrm{pH} 7.2$ ) and $1 \mathrm{mM}$ sodium diethyl diethyldithiocarbamate. The homogenate was centrifuged at $22,000 \times g$ for $20 \mathrm{~min}$ at $4^{\circ} \mathrm{C}$. After centrifugation, $100 \mu \mathrm{l}$ of the supernatant was reacted with $1.9 \mathrm{ml}$ of a solution containing $100 \mathrm{mM}$ sodium phosphate buffer (pH 7.2), $1 \mathrm{mM}$ diethyl sodium diethyldithiocarbamate, and $0.25 \mathrm{mM}$ $p$-nitrotetrazolium blue. The $\mathrm{O}_{2}{ }^{--}$concentration was determined by subtracting the absorbance of the final product from the initial absorbance at $540 \mathrm{~nm}$ (Chaitanya and Naithani 1994).

Experimental design and data analysis. An experiment consisting of two cultivars (TMG 132 and Fundacep 59) was arranged in a completely randomized design with 12 replications to evaluate the TSS and the NL. A $2 \times 2 \times 4$ factorial experiment consisting of noninoculated and inoculated plants of two cultivars and four sampling times $(4,6,8$, and 10 dai) with four replications was arranged in a completely randomized design to obtain the leaf samples for the biochemical analysis. All experiments were repeated once. Data from one representative experiment is shown in the Tables and Figures. Each experimental unit consisted of a 2 liter plastic pot with two plants. All data were analyzed using analysis of variance (ANOVA) and the means from the treatments were compared using $t$ test $(P \leq 0.05)$ using SAS (version 6.12; SAS Institute, Inc., Cary, NC). For TSS, the ANOVA was conducted on a $2 \times 4$ factorial experiment with two cultivars and four evaluation times (4, 6, 8, and 10 dai). For the NL and AUDPC, a one-way ANOVA was used to analyze the two cultivars. For the biochemical variables, the ANOVA was conducted on a $2 \times 2 \times 4$ factorial design consisting of two cultivars, plant inoculation type (noninoculated and inoculated plants), and four sampling times (4, 6, 8, and 10 dai). The Pearson correlation technique was used to determine the relationships between TSS and the activities of SOD, CAT, POX, APX, GPX, GST, and LOX as well as the concentrations of AsA, MDA, $\mathrm{H}_{2} \mathrm{O}_{2}$, and $\mathrm{O}_{2}{ }^{--}$.

\section{RESULTS}

NL and AUDPC. The cultivar (C) and sampling time (ST) factors as well as their interaction were significant for TSS, whereas $\mathrm{C}$ was significant for NL and AUDPC (Table 1). The pattern of 
target spot lesion development on the adaxial surface of the soybean leaves of the TMG 132 and Fundacep 59 cultivars is illustrated in Figure 1A. The leaves of plants from TMG 132 contained numerous, larger necrotic lesions that coalesced and were surrounded by welldeveloped chlorotic halos in comparison with Fundacep 59. The NL was significantly reduced by $14 \%$ in plants from Fundacep 59 compared with plants from TMG 132 (Fig. 1B). Plants from Fundacep 59 showed TSS values that were significantly lower, by 50 , 13,21 , and $19 \%$ at $4,6,8$, and 10 dai, respectively, than those of plants from TMG 132 (Fig. 1C). The AUDPC was significantly lower, by $15 \%$, in plants from Fundacep 59 than in plants from TMG 132 (Fig. 1D).

Antioxidant enzymes activities. The factors C, plant inoculation (PI), and ST were significant for SOD, POX, APX, and GR activities as well as for the concentrations of AsA and $\mathrm{O}_{2}{ }^{-}$ (Table 1). For the activities of CAT and GST, only PI and ST were significant. The factors $\mathrm{C}$ and PI were significant for GPX activity and the concentrations of MDA and $\mathrm{H}_{2} \mathrm{O}_{2}$. The activities of SOD, CAT, POX, APX, GPX, GR, and GST, as well as the concentrations of AsA, MDA, $\mathrm{H}_{2} \mathrm{O}_{2}$, and $\mathrm{O}_{2}{ }^{--}$were significantly influenced by at least one of the two-way and three-way interactions (Table 1). For TMG 132, POX activity significantly increased by $39,60,39$, and $70 \%$, GPX activity by $63,77,82$, and $93 \%$, and GST activity by 77 , 43,83 , and 44\%, respectively, at 4, 6, 8, and 10 dai, for the inoculated plants in comparison with the noninoculated ones (Fig. 2). Significant increases of 51, 76, 70 and $98 \%$ for POX activity, of $142,117,91$, and $127 \%$ for GPX activity, of 73, 23, 34 and $50 \%$ for GR activity, and of $123,41,62$, and $85 \%$ for GST activity, respectively, at 4, 6, 8 and 10 dai, occurred for the inoculated plants from Fundacep 59 in comparison with the noninoculated ones. For inoculated plants from TMG 132, the activities of SOD, CAT, APX, and GR were significantly greater by 31,11 , and $22 \%$ at 6,8 , and 10 dai, by $28 \%$ at 6 dai, by $17 \%$ at 4 dai, and by 62 and $29 \%$ at 4 and 10 dai, respectively, relative to their noninoculated counterparts (Fig. 2). SOD activity significantly increased by 21,21 , and $46 \%$ at 6,8 , and 10 dai, CAT by 26 and $15 \%$ at 6 and 10 dai, APX by 37, 32, and $68 \%$ at 4,8 , and 10 dai, and GR by $73,23,34$, and $50 \%$ at $4,6,8$, and 10 dai for inoculated plants from Fundacep 59 in comparison with the noninoculated counterparts (Fig. 2). GST activity significantly increased by $9 \%$ at 4 dai for the noninoculated plants from TMG 132 in comparison with the noninoculated plants from Fundacep 59

TABLE 1. Analysis of variance of the effects of the cultivar (C), plant inoculation (PI), and sampling time (ST) on target spot severity (TSS), number of lesions (NL) per square centimeter of leaflet, area under the disease progress curve (AUDPC), and the activities of superoxide dismutase (SOD), catalase (CAT), peroxidase (POX), ascorbate peroxidase (APX), glutathione peroxidase (GPX), glutathione reductase (GR), and glutathione S-transferase (GST) as well as the concentrations of ascorbate (AsA), malondialdehyde (MDA), hydrogen peroxide $\left(\mathrm{H}_{2} \mathrm{O}_{2}\right)$, and superoxide $\left(\mathrm{O}_{2}{ }^{-}\right)$in soybean plants from TMG 132 and Fundacep 59 cultivars inoculated with Corynespora cassiicola $^{\mathrm{a}}$

\begin{tabular}{lccccccc}
\hline Variables & $\mathrm{C}$ & $\mathrm{PI}$ & $\mathrm{ST}$ & $\mathrm{C} \times \mathrm{PI}$ & $\mathrm{C} \times \mathrm{ST}$ & $\mathrm{PI} \times \mathrm{ST}$ & $\mathrm{C} \times \mathrm{PI} \times \mathrm{ST}$ \\
\hline $\mathrm{TSS}$ & $* * *$ & - & $* * *$ & - & $* * *$ & - & - \\
$\mathrm{NL}$ & $* * *$ & - & - & - & - & - & - \\
$\mathrm{AUDPC}$ & $* * *$ & - & - & - & - & - & - \\
$\mathrm{SOD}$ & $* *$ & $* * *$ & $* * *$ & $* *$ & $\mathrm{~ns}$ & $* *$ & $\mathrm{~ns}$ \\
$\mathrm{CAT}$ & $\mathrm{ns}$ & $* * *$ & $* *$ & $\mathrm{~ns}$ & $\mathrm{~ns}$ & $* *$ & $\mathrm{~ns}$ \\
$\mathrm{POX}$ & $* *$ & $* * *$ & $* * *$ & $* *$ & $\mathrm{~ns}$ & $* *$ & $\mathrm{~ns}$ \\
$\mathrm{APX}$ & $*$ & $* * *$ & $* * *$ & $* *$ & $\mathrm{~ns}$ & $* *$ & $\mathrm{~ns}$ \\
$\mathrm{GPX}$ & $* *$ & $* * *$ & $\mathrm{~ns}$ & $* *$ & $\mathrm{~ns}$ & $\mathrm{~ns}$ & $\mathrm{~ns}$ \\
$\mathrm{GR}$ & $* * *$ & $* * *$ & $* *$ & $*$ & $\mathrm{~ns}$ & $* * *$ & $\mathrm{~ns}$ \\
$\mathrm{GST}$ & $\mathrm{ns}$ & $* * *$ & $* * *$ & $\mathrm{~ns}$ & $\mathrm{~ns}$ & $* * *$ & $*$ \\
$\mathrm{AsA}$ & $* * *$ & $* * *$ & $* * *$ & $* * *$ & $*$ & $\mathrm{~ns}$ & $\mathrm{~ns}$ \\
$\mathrm{MDA}$ & $* *$ & $* * *$ & $\mathrm{~ns}$ & $* *$ & $\mathrm{~ns}$ & $\mathrm{~ns}$ & $\mathrm{~ns}$ \\
$\mathrm{H}_{2} \mathrm{O}{ }_{2}$ & $* *$ & $* * *$ & $\mathrm{~ns}$ & $* *$ & $\mathrm{~ns}$ & $\mathrm{~ns}$ & $\mathrm{~ns}$ \\
$\mathrm{O}_{2}{ }^{--}$ & $* * *$ & $* * *$ & $* * *$ & $* *$ & $\mathrm{~ns}$ & $* * *$ & $\mathrm{~ns}$ \\
\hline
\end{tabular}

a Levels of probability: $\mathrm{ns}=$ nonsignificant, $*=0.05$, $* *=0.01$, and $* * *=$ $<0.001 .-=$ not determined.
(Fig. 2). For the inoculated plants from Fundacep 59, the activities of SOD, APX, GPX, GR, and GST significantly increased, respectively, by 10 and $19 \%$ at 8 and 10 dai, by 19 and $35 \%$ at 4 and 10 dai, by 16 and $15 \%$ at 4 and 6 dai, by 31 and $18 \%$ at 6 and 10 dai, and by $16 \%$ at 4 dai, respectively. POX activity significantly decreased by $10 \%$ at 4 dai for inoculated plants from TMG 132 in comparison with inoculated plants from Fundacep 59 (Fig. 2).

Concentrations of AsA, MDA, $\mathrm{H}_{2} \mathrm{O}_{2}$, and $\mathrm{O}_{2} \cdot{ }^{-}$. The factors $\mathrm{C}, \mathrm{PI}$, and $\mathrm{ST}$ were significant for the concentrations of AsA and $\mathrm{O}_{2}^{--}$(Table 1). The factors $\mathrm{C}$ and PI were significant for the concentrations of MDA and $\mathrm{H}_{2} \mathrm{O}_{2}$. The concentrations of AsA, MDA, $\mathrm{H}_{2} \mathrm{O}_{2}$, and $\mathrm{O}_{2}{ }^{-}$were significantly influenced by at least one of the two-way and three-way interactions (Table 1). For TMG 132,
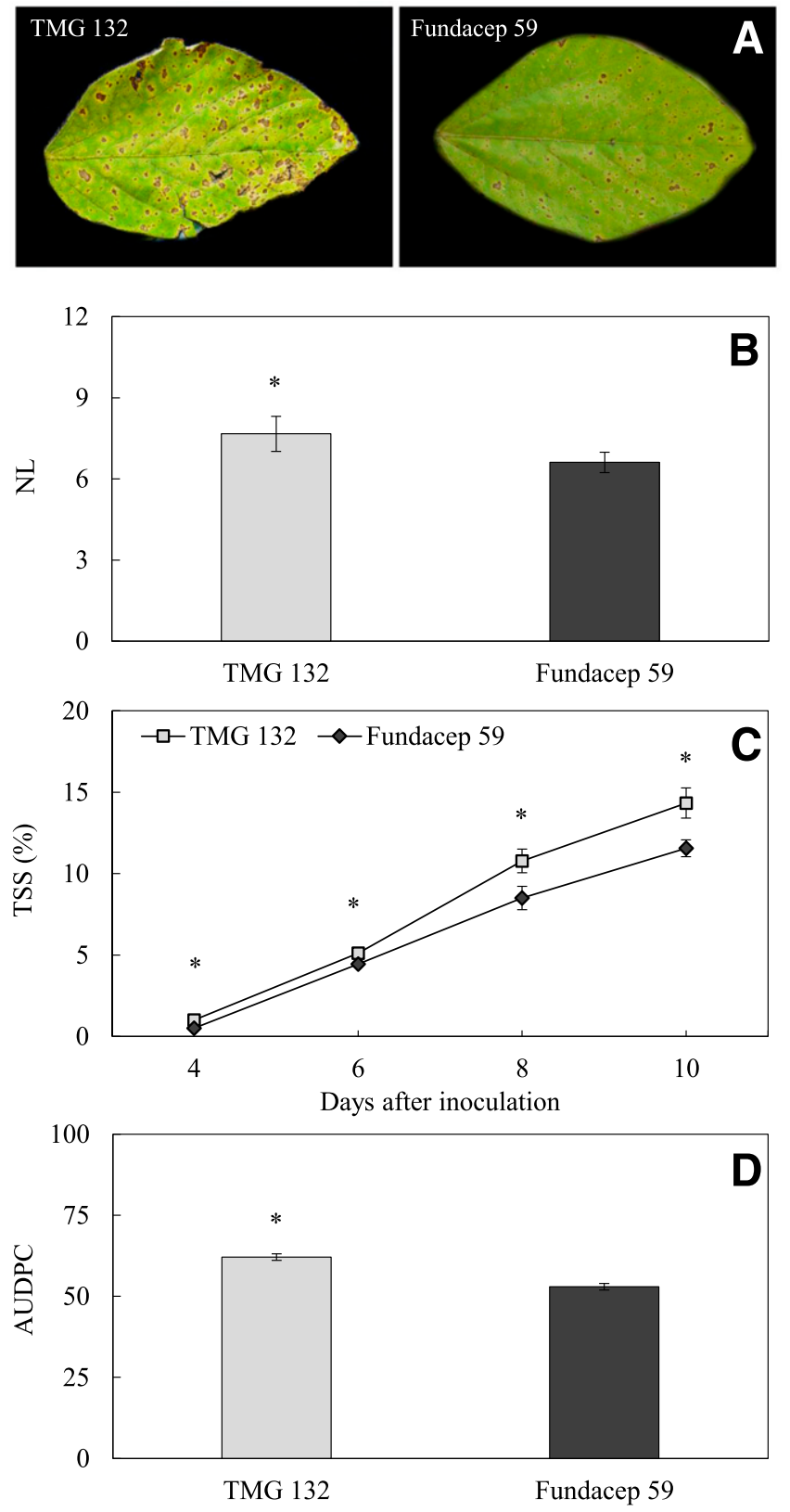

Fig. 1. A, Symptoms of target spot, B, number of lesions (NL) per square centimeter of leaflet, $\mathbf{C}$, target spot severity (TSS), and $\mathbf{D}$, the area under the disease progress curve (AUDPC) on soybean cultivars TMG 132 (susceptible) and Fundacep 59 (resistant) inoculated with Corynespora cassiicola. The means marked by an asterisk $(*)$ indicate significant difference $(P \leq 0.05)$ as determined using $t$ test. The bars represent the standard error of the mean. Two experiments were conducted with similar results, so results from one experiment are shown. 

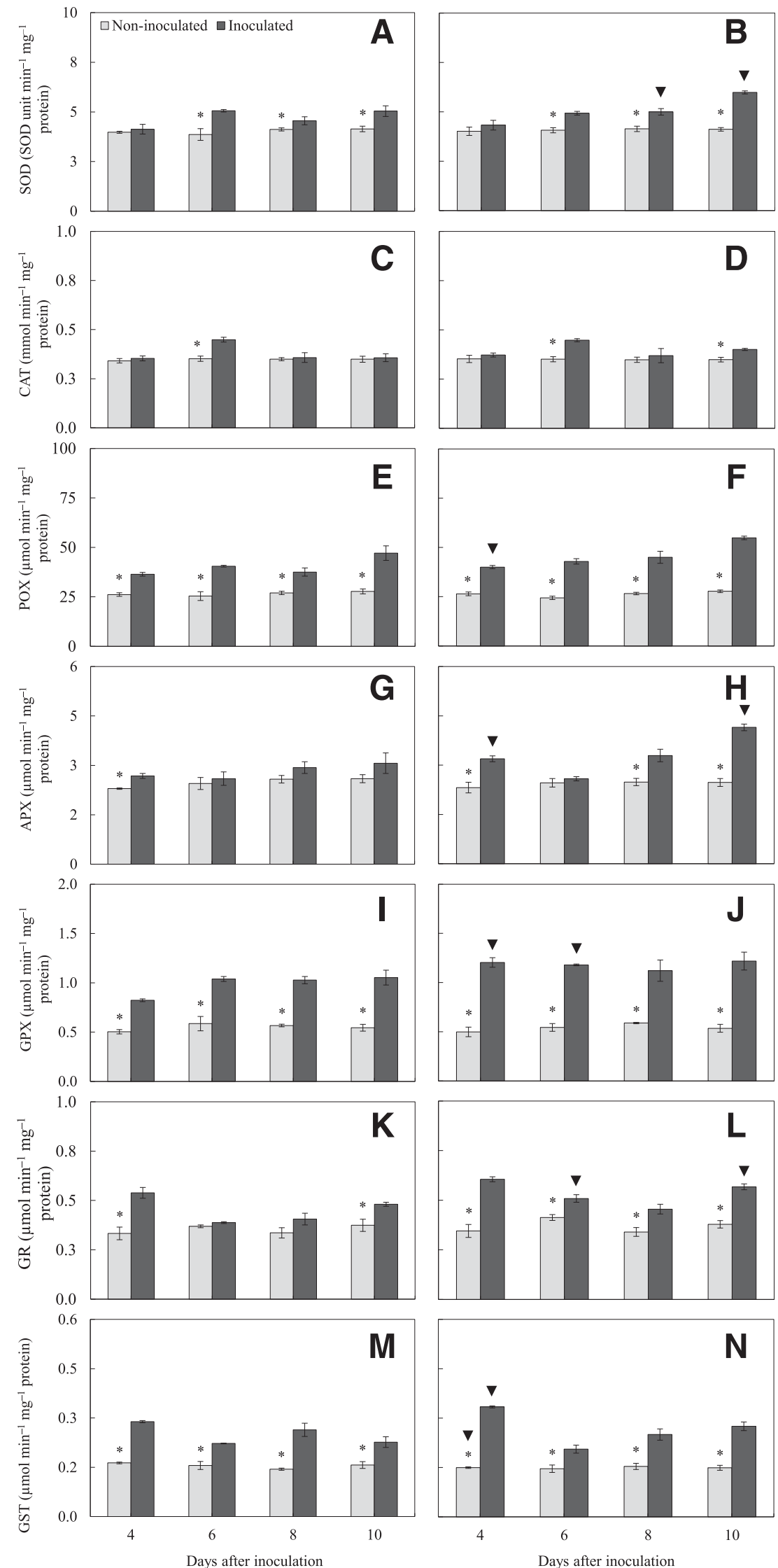

Fig. 2. Activities of $\mathbf{A}$ and $\mathbf{B}$, superoxide dismutase (SOD), $\mathbf{C}$ and D, catalase (CAT), $\mathbf{E}$ and $\mathbf{F}$, peroxidase (POX), $\mathbf{G}$ and $\mathbf{H}$, ascorbate peroxidase (APX), I and $\mathbf{J}$, glutathione peroxidase (GPX), $\mathbf{K}$ and $\mathbf{L}$, reductase glutathione (GR), and $\mathbf{M}$ and $\mathbf{N}$, glutathione $S$-transferase (GST) on soybean cultivars TMG 132 (susceptible) (A, C, E, G, I, K, and M) and Fundacep 59 (resistant) (B, D, F, H, J, L, and N) not inoculated (NI) or inoculated (I) with Corynespora cassiicola. The means marked by an asterisk $(*)$ indicate significant difference $(P \leq 0.05)$ using $t$ test between the NI and I treatments. The means marked by an inverted triangle $(\boldsymbol{\nabla})$ indicate significant difference $(P \leq 0.05)$ using $t$ test between cultivars. The bars represent the standard error of the mean. Two experiments were conducted with similar results, so results from one experiment are shown. 
AsA concentration significantly increased by 22 and $14 \%$ at 6 and 8 dai, MDA concentration by 16,22 , and $36 \%$ at 6,8 , and 10 dai, $\mathrm{H}_{2} \mathrm{O}_{2}$ concentration by $18,13,15$, and $16 \%$ at $4,6,8$, and 10 dai, and $\mathrm{O}_{2}{ }^{-}$ concentration by 32,50 , and $85 \%$ at 6,8 , and 10 dai, respectively, for the inoculated plants in comparison with the noninoculated ones (Fig. 3). Significant increases of 69, 56, 49, and 52\% for AsA concentration at $4,6,8$, and 10 dai and of 35 and $66 \%$ for $\mathrm{O}_{2}{ }^{-}$ concentration at 8 and 10 dai, respectively, occurred for the inoculated plants from Fundacep 59 in comparison with the noninoculated ones. For inoculated plants from Fundacep 59, AsA concentration significantly increased by $65,56,48$, and $52 \%$, respectively, at $4,6,8$, and 10 dai in comparison with plants from TMG 132. The MDA concentration increased by $23 \%$ at 10 dai, the $\mathrm{H}_{2} \mathrm{O}_{2}$ concentration by 11 and $9 \%$, respectively, at 8 and 10 , and the $\mathrm{O}_{2} \cdot-$ concentration by $26 \%$ at 6 dai for the inoculated plants from TMG 132 in comparison with inoculated plants from Fundacep 59 (Fig. 3).

Correlation analysis. For TMG 132, several significant positive and negative correlations were observed. TSS was positively correlated with the activities of POX, GPX, and $\mathrm{O}_{2}^{\cdot-}$ concentration
(Table 2). The SOD activity was positively correlated with both POX activity and AsA concentration and negatively correlated with GST activity. The CAT activity was negatively correlated with the activities of GR and POX and positively correlated with APX activity. The POX activity was positively correlated with AsA concentration and the GST activity was negatively correlated with $\mathrm{O}_{2}{ }^{--}$concentration (Table 2). For Fundacep 59, there were positive correlations among TSS, the activities of SOD, POX, and APX and the concentration of $\mathrm{O}_{2}^{--}$. The POX activity was positively correlated with both APX activity and $\mathrm{O}_{2} \cdot{ }^{--}$concentration, whereas CAT activity was negatively correlated with GST activity (Table 2).

\section{DISCUSSION}

The present study provides evidence that the antioxidant system in soybean plants may play a pivotal role in reducing the ROS damage associated with infection by $C$. cassiicola. The production of ROS in plants due to infection by pathogens is a well-documented phenomenon (Daub et al. 2013; Knörzer et al. 1999). Whatever their origin, ROS accumulation leads to oxidative damage in host cells,
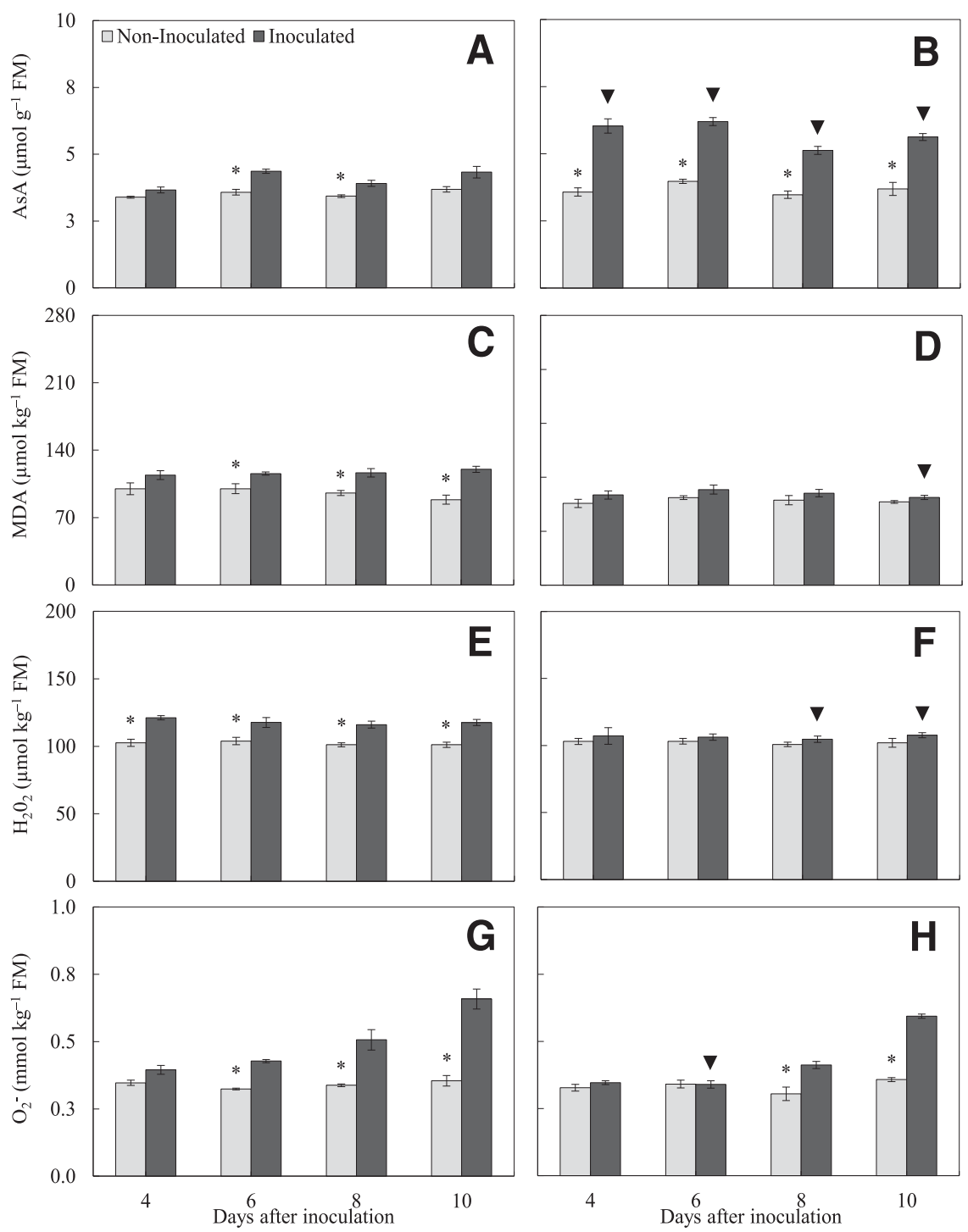

Fig. 3. Concentrations of $\mathbf{A}$ and $\mathbf{B}$, ascorbate (AsA), $\mathbf{C}$ and $\mathbf{D}$, malondialdehyde (MDA), $\mathbf{E}$ and $\mathbf{F}$, hydrogen peroxide $\left(\mathrm{H}_{2} \mathrm{O}_{2}\right)$, and $\mathbf{G}$ and $\mathbf{H}$, superoxide $\left(\mathrm{O}_{2}{ }^{\cdot-}\right)$ on soybean cultivars TMG 132 (susceptible) (A, C, E, and G) and Fundacep 59 (resistant) (B, D, F, and H) not inoculated (NI) or inoculated (I) with Corynespora cassiicola. The means marked by an asterisk $(*)$ indicate significant difference $(P \leq 0.05)$ using $t$ test between NI and I treatments. The means marked by an inverted triangle $(\boldsymbol{\nabla})$ are significantly different $(P \leq 0.05)$ using $t$ test between cultivars within each sampling time and for the NI or I treatments that are followed. The bars represent the standard error of the mean. Two experiments were conducted with similar results, so the results from one experiment are shown. FM $=$ fresh matter. 
which favors infection by necrotrophic pathogens (Daub et al. 2013; Heller and Tudzynski 2011). Consistent with previous studies (Godoy et al. 2012; Pitol et al. 2011), Fundacep 59 were more resistant to target spot than plants from TMG 132 as indicated by the reduced TSS, NL, and AUDPC values. However, information about the underlying mechanisms involved in soybean resistance to target spot is still lacking in the literature.

The production of ROS and lipid peroxidation, considered to be the two biochemical markers for assessing lipid destruction following an oxidative burst, are among the first defense reactions induced at the early stages of fungal infection (Apel and Hirt 2004; Blokhina and Fagerstedt 2010). In the present study, significant increases in $\mathrm{O}_{2}{ }^{-}$concentration in response to $C$. cassiicola infection occurred in both TMG 132 and Fundacep 59. However, the inoculated plants from Fundacep 59 were more efficient at the removal of $\mathrm{O}_{2}{ }^{--}$in the late stages of $C$. cassiicola infection than TMG 132. These results are in line with the study by Debona et al. (2012) who reported that wheat plants from a resistant cultivar were better able to detoxify $\mathrm{O}_{2}{ }^{-}$than those from a susceptible cultivar during the course of Pyricularia oryzae infection. The high levels of ROS generated in the roots of tomato plants infected by $F$. oxysporum f. sp. lycopersici resulted in an increase in lipid peroxidation and the concurrent production of MDA (Mandal et al. 2008). Similarly, an increase in MDA concentration was observed for the inoculated plants from TMG 132 in this study. Because MDA is a product of lipid peroxidation, the lower concentrations of $\mathrm{O}_{2}{ }^{--}$ recorded for plants from Fundacep 59 could explain, at least in part, their lower MDA concentration than those of the plants from TMG 132.

The SOD is one of the most important scavenger enzymes and represents the first line of defense against ROS through its catalysis of the dismutation of $\mathrm{O}_{2} \cdot-$ to $\mathrm{H}_{2} \mathrm{O}_{2}$ and oxygen $\left(\mathrm{O}_{2}\right)$ (Giannopolitis and Ries 1977; Gill and Tuteja 2010; Hao et al. 2011). In the present study, SOD activity increased for plants from both cultivars in response to $C$. cassiicola infection, which is consistent with what has been obtained for the tomato-B. cinerea (Kużniak and Skłodowska 2005), strawberry-Mycosphaerella fragariae (Ehsani-Moghaddam et al. 2006), and wheat-P. oryzae (Debona et al. 2012) interactions. However, in this study, a high degree of SOD activity was recorded in the late stages of $C$. cassiicola infection for plants from Fundacep 59 compared with plants from TMG 132. Therefore, the SOD activity contributed to the lower $\mathrm{O}_{2}{ }^{-}$concentration and the reduced damage to the plant cell plasma membrane observed in the former cultivar as indicated by the lower concentration of MDA. In strawberry and wheat plants infected with Mycosphaerella fragariae (Ehsani-Moghaddam et al. 2006) and P. oryzae (Debona et al. 2012), respectively, greater concentrations of SOD activity in plants from resistant cultivars than susceptible ones were observed in response to fungal infection. Therefore, it is believed that SOD, by reducing the $\mathrm{O}_{2}^{--}$concentration and the consequent cellular damage, plays an important role in soybean resistance to target spot.

The $\mathrm{H}_{2} \mathrm{O}_{2}$ is another ROS generated during pathogen infection or by $\mathrm{O}_{2}{ }^{--}$dismutation via SOD (Lanubile et al. 2012). For this reason, an increase in the activities of CAT, APX, and POX, which are involved in $\mathrm{H}_{2} \mathrm{O}_{2}$ removal, is required to lower the concentration of $\mathrm{H}_{2} \mathrm{O}_{2}$ (Foyer and Noctor 2011; Gill and Tuteja 2010; Mittler et al. 2004). The findings of this study highlighted that the activities of CAT, APX, and POX increased upon C. cassiicola infection. The activity of peroxisomal CAT on tomato plants in response to $B$. cinerea infection was greater but was followed by a strong decline during the late stages of fungal infection compared with noninoculated plants (Kużniak and Skłodowska 2005). In the current study, the activities of CAT, APX, and POX were greater in plants from Fundacep 59 than plants from TMG 132. In agreement with these results, Magbanua et al. (2007) demonstrated that CAT activity was greater in the resistant maize lines to Aspergillus flavus than in susceptible ones. In the wheat-Rhizoctonia cerealis interaction, POX activity was greater in a resistant than in a susceptible cultivar (Hong-xia et al. 2011). The high POX and APX activities were also associated with wheat resistance to leaf blast (Debona et al. 2012). Polkowska-Kowalczyk et al. (2007) demonstrated that in the Solanum tuberosum-Phytophthora infestans interaction, APX activity was significantly greater in the resistant cultivar than in the susceptible one. The increases in the activities of CAT, POX, and APX in the inoculated Fundacep 59 plants could have protected the plant cells from the cytotoxic effects of $\mathrm{H}_{2} \mathrm{O}_{2}$.

The AsA is considered to be one of the most powerful ROS scavengers and acts as an electron donor to APX to reduce $\mathrm{H}_{2} \mathrm{O}_{2}$ to water (Foyer and Noctor 2011). In the present study, the AsA concentration in plants from both cultivars increased upon C. cassiicola infection. However, a greater accumulation of AsA was observed in plants from Fundacep 59 than in plants from TMG 132. In the $S$. tuberosum $-P$. infestans interaction, the concentration of AsA, as well as the activity of APX were also significantly greater in the resistant than in the susceptible cultivar. Furthermore, it has been suggested that APX and AsA played an important role in the regulation of ROS levels upon $P$. infestans infection (PolkowskaKowalczyk et al. 2007). These findings also support what was proposed for the soybean-C. cassiicola interaction in the present study.

The GPX and GST are important enzymes for the alleviation of oxidative stress in plant cells and they use GSH to reduce $\mathrm{H}_{2} \mathrm{O}_{2}$ and other hydroperoxides (Gill and Tuteja 2010). In the inoculated plants from TMG 132 and Fundacep 59, there was a consistent increase in the activities of GPX and GST during the C. cassiicola infection process. In contrast, Debona et al. (2012) observed

TABLE 2. Pearson correlation coefficients among target spot severity (TSS), the activity of superoxide dismutase (SOD), catalase (CAT), peroxidase (POX), ascorbate peroxidase (APX), glutathione peroxidase (GPX), glutathione reductase (GR), and glutathione S-transferase (GST) and the concentrations of ascorbate (AsA), malondialdehyde (MDA), hydrogen peroxide $\left(\mathrm{H}_{2} \mathrm{O}_{2}\right)$, and superoxide $\left(\mathrm{O}_{2}{ }^{--}\right)$in soybean plants from TMG 132 (above the diagonal) and Fundacep 59 (below the diagonal) cultivars inoculated with Corynespora cassiicola ${ }^{\text {a }}$

\begin{tabular}{|c|c|c|c|c|c|c|c|c|c|c|c|c|}
\hline Variables & TSS & SOD & CAT & POX & APX & GPX & GR & GST & AsA & MDA & $\mathrm{H}_{2} \mathrm{O}_{2}$ & $\mathrm{O}_{2}^{\cdot-}$ \\
\hline TSS & $\ldots$ & 0.35 & -0.17 & $0.51 *$ & 0.39 & $0.60 *$ & -0.27 & -0.40 & 0.40 & 0.26 & -0.25 & $0.82 * * *$ \\
\hline SOD & $0.78 * * *$ & $\ldots$ & 0.27 & $0.65^{* *}$ & 0.34 & 0.36 & -0.27 & $-0.53 *$ & $0.57^{*}$ & -0.03 & 0.17 & 0.19 \\
\hline CAT & -0.02 & 0.21 & $\ldots$ & 0.32 & 0.04 & 0.49 & $-0.53 *$ & -0.13 & 0.28 & -0.15 & -0.15 & -0.40 \\
\hline POX & $0.77 * * *$ & $0.90 * * *$ & 0.16 & ... & $0.55^{*}$ & 0.45 & -0.05 & -0.06 & $0.56^{*}$ & -0.11 & 0.09 & 0.24 \\
\hline APX & $0.63^{* *} *$ & $0.54 *$ & -0.10 & $0.67 * *$ & $\ldots$ & 0.31 & -0.14 & 0.04 & 0.26 & -0.40 & 0.11 & 0.15 \\
\hline GPX & $-0.02^{\mathrm{ns}}$ & 0.20 & 0.00 & 0.35 & 0.12 & $\ldots$ & -0.49 & -0.32 & 0.17 & 0.19 & -0.23 & 0.31 \\
\hline GR & -0.31 & -0.18 & 0.09 & -0.07 & 0.32 & 0.08 & $\ldots$ & 0.44 & -0.35 & 0.13 & 0.46 & -0.05 \\
\hline GST & -0.31 & -0.16 & $-0.53^{*}$ & 0.01 & 0.21 & 0.24 & 0.43 & $\ldots$ & -0.48 & -0.05 & 0.39 & $-0.53^{*}$ \\
\hline AsA & -0.48 & -0.23 & 0.17 & -0.14 & -0.34 & 0.42 & 0.32 & 0.08 & $\ldots$ & -0.24 & -0.08 & 0.32 \\
\hline MDA & -0.16 & -0.30 & 0.26 & -0.42 & -0.38 & -0.24 & 0.02 & -0.30 & -0.12 & $\ldots$ & 0.24 & 0.27 \\
\hline $\mathrm{H}_{2} \mathrm{O}_{2}$ & -0.01 & 0.02 & -0.18 & 0.05 & 0.03 & 0.27 & 0.09 & 0.13 & 0.19 & 0.12 & $\ldots$ & -0.37 \\
\hline $\mathrm{O}_{2}^{\cdot-}$ & $0.83 * * *$ & $0.75 * * *$ & -0.03 & $0.76^{* * * *}$ & $0.82 * * *$ & 0.07 & 0.12 & 0.05 & -0.32 & -0.30 & 0.03 & ... \\
\hline
\end{tabular}

${ }^{\mathrm{a}}$ Levels of probability: ${ }^{\mathrm{ns}}=$ not significant, $*=0.05, * *=0.01$, and $* * *=0.0001$. 
increases in GPX activity only for the inoculated plants from a susceptible cultivar in the wheat $-P$. oryzae interaction. The activities of GPX and GST were greater in plants from Fundacep 59 than in plants from TMG 132 in the early stages of C. cassiicola infection. Accordingly, GST appeared to be one of the most important antioxidant enzymes involved in wheat resistance to leaf blast (Debona et al. 2012). In contrast, Polkowska-Kowalczyk et al. (2007) demonstrated that a resistant genotype of potato showed lower GST activity in response to $P$. infestans infection. Therefore, it seems reasonable to assume that GPX and GST play a key role in soybean resistance to target spot through the removal of $\mathrm{H}_{2} \mathrm{O}_{2}$ and, therefore, the products contributing to lipid peroxidation.

The GR belongs to the Foyer-Halliwell-Asada pathway, whose function is to scavenge ROS in the plastids and, possibly, the extraplastidic compartments of the plant cell (Foyer and Noctor 2011; Noctor and Foyer 1998). The activity of GR was found to be greater in the inoculated plants than in the noninoculated ones, especially for Fundacep 59. Conversely, at the early stages of $B$. cinerea infection in tomato plants, GR activity decreased in comparison with noninfected plants (Kużniak and Skłodowska 2005). The level of GR activity in plants from a resistant apricot cultivar was greater than in a susceptible one following infection with Plum pox virus (Hernández et al. 2001). In a study involving potato and an elicitor derived from $P$. infestans, the increase in GR activity at an early phase following treatment with a culture filtrate was greater in the susceptible than in the resistant cultivars (Polkowska-Kowalczyk et al. 2007). However, the data from the present study suggest that higher GR activity in the plants from both cultivars, but to a greater extent in the resistant one, contribute to the maintenance of high levels of GSH and the alleviation of the oxidative stress caused by $C$. cassiicola infection.

The results from the present study indicate that a more efficient antioxidative system, which is involved in the removal of ROS generated in soybean plants during $C$. cassiicola infection, reduces cellular damage and contributes to increased resistance to target spot. Further research that aims to investigate the antioxidant system in the most productive soybean cultivars will play a pivotal role in the development of biochemical markers that can be used in breeding programs to select cultivars that can be grown in areas subject to severe epidemics of target spot.

\section{ACKNOWLEDGMENTS}

This study is part of a Ph.D. thesis presented by A. A. Fortunato at the Department of Plant Pathology, Universidade Federal de Viçosa. A. A. Fortunato was supported by FAPEMIG. F. A. Rodrigues thanks the CNPq for his fellowship. The authors thank C. Dinali Santos Seixas and H. Diniz Campos for providing the two cultivars of soybean and the C. cassiicola isolate used in this study, respectively. We thank J. Cupertino Pinheiro for his technical assistance.

\section{LITERATURE CITED}

Almeida, A. M. R., Ferreira, L. P., Yorinori, J. T., Silva, J. F. V., Henning, A. A., Godoy, C. V., Costamilan, L. M., and Meyer, M. C. 2005. Doenças da Soja (Glycine $\max$ (L.) Merril. Pages 569-588 in: Manual de Fitopatologia: Doenças das Plantas Cultivadas, 4th. H. Kimati, L. Amorim, J. A. M. Rezende, A. Bergamin Filho, and L. E. A. Camargo, eds. Ceres, São Paulo, SP.

Anderson, D., Prasad, K., and Stewart, R. 1995. Changes in isozyme profiles of catalase, peroxidase and glutathione reductase during acclimation to chilling in mesocotyls of maize seedlings. Plant Physiol. 109:1247-1257.

Anderson, J. V., and Davis, D. G. 2004. Abiotic stress alters transcript profiles and activity of glutathione-S-transferase, glutathione peroxidase, and glutathione reductase in Euphorbia esula. Physiol. Plant. 120:421-433.

Apel, K., and Hirt, H. 2004. Reactive oxygen species: Metabolism, oxidative stress, and signal transduction. Annu. Rev. Plant Biol. 55:373-399.

Asada, K. 1999. The water-water cycle in chloroplasts: Scavenging of active oxygen and dissipation of excess photons. Annu. Rev. Plant Biol. 50:601-639.

Barthe, P., Pujade-Renaud, V., Breton, F., Gargani, D., Thai, R., Roumestand, C., and Lamotte, F. 2007. Structural analysis of cassiicolin, a host-selective protein toxin from Corynespora cassiicola. J. Mol. Biol. 367:89-101.
Beauchamp, C., and Fridovich, I. 1971. Superoxide dismutase: Improved assays and an assay applicable to acrylamide gels. Anal. Biochem. 44: 276-287.

Blokhina, O., and Fagerstedt, K. V. 2010. Oxidative metabolism, ROS and NO under oxygen deprivation. Plant Physiol. Biochem. 48:359-373.

Bradford, M. N. 1976. A rapid and sensitive method for the quantitation of microgram quantities of protein utilizing the principle of protein-dye binding. Anal. Biochem. 72:248-254.

Cakmak, I., and Marschner, H. 1992. Magnesium deficiency and high light intensity enhance activities of superoxide dismutase, ascorbate peroxidase and glutathione reductase in bean leaves. Plant Physiol. 98:1222-1227.

Cakmak, L., and Horst, W. J. 1991. Effect of aluminum on lipid peroxidation, superoxide dismutase, catalase, and peroxide activity in root tip of soybean (Glycine max). Plant Physiol. 83:463-468.

Carlberg, C., and Mannervik, B. 1985. Glutathione reductase. Methods Enzymol. 113:488-495.

Chaitanya, K. K., and Naithani, S. C. 1994. Role of superoxide, lipid peroxidation and superoxide dismutase in membrane perturbation during loss of viability in seeds of Shorea robusta Gaertn. f. New Phytol. 126:623-627.

Chance, B., and Maehley, A. C. 1955. Assay of catalases and peroxidases. Methods Enzymol. 2:764-775.

Dallagnol, L. J., Rodrigues, F. A., Tanaka, F. A. O., Amorim, L., and Camargo, L. E. A. 2012. Effect of potassium silicate on epidemic components of powdery mildew on melon. Plant Pathol. 61:323-330.

Daub, M. E., Herrero, S., and Chung, K. R. 2013. Reactive oxygen species in plant pathogenesis: The role of perylenequinone photosensitizers. Antioxid. Redox Signal. 19:970-989.

Debona, D., Rodrigues, F. A., Rios, J. A., and Nascimento, K. J. T. 2012. Biochemical changes in the leaves of wheat plants infected by Pyricularia oryzae. Phytopathology 102:1121-1129.

Del Longo, O. T., González, C. A., Pastori, G. M., and Trippi, V. S. 1993. Antioxidant defenses under hyperoxygenic and hyperosmotic conditions in leaves of two lines of maize with differential sensitivity to drought. Plant Cell Physiol. 34:1023-1028.

Dhingra, O. D., and Sinclair, J. B. 1995. Basic Plant Pathology Methods, 2nd Ed. Lewis Publishers, Boca Raton, FL.

Ehsani-Moghaddam, B., Charles, M. T., Carisse, O., and Khanizadeh, S. 2006. Superoxide dismutase responses of strawberry cultivars to infection by Mycosphaerella fragariae. J. Plant Physiol. 163:147-153.

Fehr, W. R., Caviness, C. E., Burmood, D. T., and Pennington, J. S. 1971. Stage of development descriptions for soybeans, Glycine max (L.). Merrill. Crop Sci. 11:929-931.

Foyer, C. H., and Halliwell, B. 1976. The presence of glutathione and glutathione reductase in chloroplasts: A proposed role in ascorbic acid metabolism. Planta 133:21-25.

Foyer, C. H., and Noctor, G. 2011. Ascorbate and glutathione: the heart of the redox hub. Plant Physiol. 155:2-18.

Gay, C., and Gerbicki, J. M. 2000. A critical evaluation of sorbitol on the ferric-xylenol orange hydroperoxide assay. Anal. Biochem. 284:217-220.

Giannopolitis, C. N., and Ries, S. K. 1977. Superoxide dismutases I. Occurrence in higher plants. Plant Physiol. 59:309-314.

Gill, S. S., and Tuteja, N. 2010. Reactive oxygen species and antioxidant machinery in abiotic stress tolerance in crop plants. Plant Physiol. Biochem. 48:909-930.

Godoy, C. V., Utiamada, C. M., Meyer, M. C., Campos, H. D., Pimenta, C. B., and Borges, E. P. 2012. Eficiência de fungicidas para o controle da mancha-alvo, Corynespora cassiicola, na safra 2011/12: Resultados sumarizados dos ensaios cooperativos, Circular Técnica, 94. Embrapa Soja, Londrina.

Grant, J. J., and Loake, G. J. 2000. Role of reactive oxygen intermediates and cognate redox signaling in disease resistance. Plant Physiol. 124:21-30.

Habig, W. H., Pabst, M. J., and Jakoby, W. B. 1974. GlutathioneS-transferases. The first enzymatic step in mercapturic acid formation. J. Biol. Chem. 249:7130-7139.

Hao, Z., Wang, L., Liang, J., and Tao, R. 2011. Expression of defense genes and activities of antioxidant enzymes in rice resistance to rice stripe virus and small brown planthopper. Plant Physiol. Biochem. 7:744-751.

Heath, R. L., and Packer, L. 1968. Photoperoxidation in isolated chloroplast. I. Kinetics and stoichometry of fatty acid peroxidation. Arch. Biochem. Biophys. 125:189-198.

Heller, J., and Tudzynski, P. 2011. Reactive oxygen species in phytopathogenic fungi: Signaling, development, and disease. Annu. Rev. Phytopathol. 49: 369-390.

Hernández, J. A., Talavera, J. M., Martínez-Gómez, P., Dicenta, F., and Sevilla, F. 2001. Response of antioxidative enzymes to Plum pox virus in two apricot cultivars. Physiol. Plant. 111:313-321.

Hong-xia, L., Zhi-yong, X., and Zeng-yan, Z. 2011. Changes in activities of antioxidant-related enzymes in leaves of resistant and susceptible wheat inoculated with Rhizoctonia cerealis. Agric. Sci. China 10:526-533. 
Kampfenkel, K., Van Montagu, M., and Inzé, D. 1995. Extraction and determination of ascorbate and dehydroascorbate from plant tissue. Anal. Biochem. 225:165-167.

Kar, M., and Mishra, D. 1976. Catalase, peroxidase, and polyphenol oxidase activities during rice leaf senescence. Plant Physiol. 57:315-319.

Kiprovski, B., Malenčić, D., Popovic, M., Budakov, D., Stojšin, V., and Baleševic-Tubic, S. 2012. Antioxidant systems in soybean and maize seedlings infected with Rhizoctonia solani. J. Plant Pathol. 94:313-324.

Knörzer, O. C., Lederer, B., Durner, J., and Böger, P. 1999. Antioxidative defense activation in soybean cells. Physiol. Plant. 107:294-302.

Kuo, M. C., and Kao, C. H. 2003. Aluminum effects on lipid peroxidation and antioxidative enzyme activity in rice leaves. Biol. Plant. 46: 149-152.

Kużniak, E., and Skłodowska, M. 2005. Fungal pathogen-induced changes in the antioxidant systems of leaf peroxisomes from infected tomato plants. Planta 222:192-200.

Lanubile, A., Bernardi, J., Marocco, A., Logrieco, A., and Paciolla, C. 2012. Differential activation of defense genes and enzymes in maize genotypes with contrasting levels of resistance to Fusarium verticillioides. Environ. Exp. Bot. 78:39-46.

Magbanua, Z. V., De Moraes, C. M., Brooks, T. D., Williams, W. P., and Luthe, D. S. 2007. Is catalase activity one of the factors associated with maize resistance to Aspergillus flavus? Mol. Plant-Microbe Interact. 20:697-706.

Malenčić, D., Kiprovski, B., Popović, M., Prvulović, D., Miladinović, J., and Djordjević, V. 2010. Changes in antioxidant systems in soybean as affected by Sclerotinia sclerotiorum (Lib.) de Bary. Plant Physiol. Biochem. 48: 903-908.

Mandal, S., Mitra, A., and Mallick, N. 2008. Biochemical characterization of oxidative burst during interaction between Solanum lycopersicum and Fusarium oxysporum f. sp. lycopersici. Physiol. Mol. Plant Pathol. 72: 56-61.

Mittler, R. 2002. Oxidative stress, antioxidants and stress tolerance. Trends Plant Sci. 7:405-410.
Mittler, R., Vanderauwera, S., Gollery, M., and Van Breusegem, F. 2004. Reactive oxygen gene network of plants. Trends Plant Sci. 9:490-498.

Nagalakshmi, N., and Prasad, M. N. V. 2001. Responses of glutathione cycle enzymes and glutathione metabolism to copper stress in Scenedesmus bijugatus. Plant Sci. 160:291-299.

Nakano, Y., and Asada, K. 1981. Hydrogen peroxide is scavenged by ascorbatespecific peroxidase in spinach chloroplasts. Plant Cell Physiol. 22:867-880.

Noctor, G., and Foyer, C. H. 1998. Ascorbate and glutathione: keeping active oxygen under control. Annu. Rev. Plant Biol. 49:249-279.

Onesirosan, P., Arny, D., and Durbin, R. D. 1975a. Increasing sporulation of Corynespora cassiicola. Mycopathologia 55:121-123.

Onesirosan, P., Mabuni, C. T., Durbin, R. D., Morin, R. B., Rich, D. H., and Arny, D. C. 1975b. Toxin production by Corynespora cassiicola. Physiol. Plant Pathol. 5:289-295.

Pitol, C., Erbes, E. J., Romeiro, T. S., Bagega, D., Valensuel, M. L. B., and Silva, L. L. 2011. Resultados de Experimentação e Campos Demonstrativos de Soja-Safra 2010/2011. Fundação MS, Maracajú, MS.

Polkowska-Kowalczyk, L., Wielgat, B., and Maciejewska, U. 2007. Changes in the antioxidant status in leaves of Solanum species in response to elicitor from Phytophthora infestans. J. Plant Physiol. 164:1268-1277.

Shaner, G., and Finney, R. E. 1977. The effect of nitrogen fertilization on the expression of slow-mildewing resistance in Knox wheat. Phytopathology 67:1051-1056.

Sinclair, J. B. 1999. Target spot. Page 27 in: Compendium of Soybean Diseases, 4th ed. American Phytopathological Society, St. Paul, MN.

Soares, R. M., Godoy, C. V., and Oliveira, M. C. N. D. 2009. Escala diagramática para avaliação da severidade da mancha alvo da soja. Trop. Plant Pathol. 34:333-338.

Teramoto, A., Machado, T. A., Santos, L. M. D., Volf, M. R., Meyer, M. C., and Cunha, M. G. D. 2013. Reaction of soybean cultivars to Corynespora cassiicola. Trop. Plant Pathol. 38:68-71.

Xavier, S. A., Canteri, M. G., Barros, D. C. M., and Godoy, C. V. 2013. Sensitivity of Corynespora cassiicola from soybean to carbendazim and prothioconazole. Trop. Plant Pathol. 38:431-435. 